\title{
Extremism Trails in Santri Cities: Discourses, Networks, and Early Detection
}

\author{
Y Effendi ${ }^{1}$, A Z Hamdi ${ }^{2}$ \\ ${ }^{1}$ Brawijaya University, Indonesia, ${ }^{2}$ Sunan Ampel Islamic State University, Indonesia \\ 1y.effendi@ub.ac.id, ${ }^{1}$ ahmadinung@uinsby.ac.id
}

\begin{abstract}
This article aimed to describe emerging Islamic extremism in santri cities, which contradicted their image as moderate regions. Employing observation, in-depth interviews, and focus group discussion, this qualitative research tried to understand discourses on extremism and intolerance, actors and their networks, and early detection in youth. The findings of this study indicated that even regions perceived as having moderate religious culture were not immune to the spread of extremist ideology and acts of intolerance. Three discourses; "others", "thaghut", and "the legitimate use of violence", were produced to build intolerant narratives in the public sphere, namely hatred towards Christians, Shia Muslims and minorities, the incompatibility of Pancasila and democracy with Islam, the adoption of Sharia law, and the legitimate use of violence for ordering good and prohibiting evil (amar ma'ruf nahi munkar). Their network was activated through out-of-town people who infiltrated moderate mass organizations and influenced pedagogic local figures. Using conventional and new media such as social media to spread their ideas to young people and women, these radical groups used "Alqamah house" as a camouflage of their movement safe house.
\end{abstract}

Keywords: Extremism, Radicalism, Discourse, Santri Cities, Political Islam

\section{INTRODUCTION}

Much of Prevention and Countering Violent Extremism (P/CVE) policies and programs have emphasized on curative or hard approach which exposes hole for its main focus on consequences of radicalization and extremist violence acts. This niche revealed a failure in understanding how contained extremist movements using a hard security approach involving the use of forceencompasses from surveillance, policing, and enactment of anti-terror laws-were still able to emerge, grow, transform, and even survive. While a soft or preventive approach, which was considered cost-effective and could maintain minimal threat, gained less attention by academics and practitioners [1].

The two santri (observant Muslim) cities of Sampang and Probolinggo witnessed this failure. Its nickname, "santri city", suggests that Islamic religiosity and santri values inspire all social life aspects [2]. Most of the public presume these coastal regions to be moderate and have developed a shielding culture towards extremist ideas. The towns may neither represent East Java nor the province's youth radicalization hotspots, yet they have drawn more than adequate national attention 
in extremist acts. Some considerations in regards to these Nahdlatul Ulama (NU) or nahdliyyinpopulated regions are as follow. In 2012, violent acts and persecutions toward Shia villagers erupted in Sampang. The angry crowd firebombed thirty seven houses and put one into death and injured tens of people badly. The community has been banished from their own home ever since. Initially, they were relocated to The Sports Center, only to be sent off to their island to Rusunawa Agro Jemundo in Sidoarjo and have been living as Internally Displaced Persons (IDP) until now [3]. While in 2018, Probolinggo sparked public uproar on female kindergarten students marching in the Indonesia Independence Day Commemoration parade wearing niqab, black robes, and property guns. The video went viral and the school was accused of propagating radical and extremist ideologies. Even local and national officials quickly absolve the kindergarten form accusations, some worried indoctrination of extremist ideas to their students [4].

The public concern of the kindergarten cultural parade could be relevant. Earlier in May, bombs exploded in three churches of Santa Maria Tak Bercela, GKI Diponegoro, Gereja Pantekosta Pusat Surabaya (GPPS) Jemaat Sawahan, Rusunawa Wonocolo Sidoarjo, and Surabaya Police Headquarter which involved children and women in their bombing amaliyah (religious deed). After the bombing, sixteen were arrested in Probolinggo as part of the case development.

This research aims to find out how far these extremist ideologies have spread in the regions. To achieve these goals, this study encompasses the prevailing Islamic discourses to identifying actor networks, radicalization strategies, and early detection efforts of younger people. The identification of these matters will allow stakeholders to develop preventive policy measures, especially how to break the chain of extremist ideologies.

\section{RESEARCH METHOD}

This research is a qualitative research, which is defined as a research procedure that produces descriptive data in the form of written or spoken words from people and observable behavior. Its emphasis is on natural settings and individual actions that hold holistic meaning [5].

Data were collected through interviews, both in the form of one-on-one, in-depth interviews and focus group discussions (FGDs), documentation, and observation. Thirty-six informants have been interviewed. They consist of government officials, police and military officers, religious leaders (kyai, clerics), teachers, and students. One-on-one interviews were held from May to September 2019. The FGD in Sampang was held in May 2019, while the FGD in Probolinggo was held in August-September 2019.

Data collected through interviews were completed with documents and field notes. Documents used in the study were mostly taken from various news media, both print and online. More observations were made to confirm interviews, for example, visits to mosques or certain neighborhoods.

\section{RESULT AND DISCUSSION}

\subsection{Discourses of Islamic Extremism}

A soft security approach to extremism required understanding the context and dynamics that enable extremist ideas to grow, transform, to be sustained and accepted by public. To analyze 
flourishing Islamic discourses (text), we need an understanding of social and situational reality (context) to guide understanding on the emergence of intolerant narratives. In Indonesia, the dominant discourse was that "there are radical Muslims but there are also normal Muslims" [6]. The struggle arises from the view that extremism or radicalism is abnormal, excessive and out of the mainstream perspective that Islam is peaceful, and that "pious Muslims are tolerant people". Our research in Sampang and Probolinggo found that three discourses that emerged were; others, thaghut (kafir or infidel system), and the legitimate the use of violence. These discourses were produced from the following narratives (or discourses, with small d):

\subsubsection{Narrations of Intolerance}

In Sampang and Probolinggo, several emerging Islamic narratives can be identified as typically extremist or could pave the way to various intolerant practices. The narratives are as follow: 1) hatred towards Christians, 2) hostility towards Shia members, 3) Pancasila and democracy are incompatible with Islam, 4) legal implementation of Sharia law, and 5) legitimate use of violence for ordering good and prohibiting evil (amar ma'ruf and nahi munkar).

\subsubsection{Hatred towards Christians}

Most informants believe that Christians are natural enemies of Islam. Christianizations were blamed for eroding Muslims quantity. A constant narrative of systematic Christianization project has been reproduced as well as accusation of its suffering from monotheism deviations. During an interview conducted on May 23, 2019, a local cleric in Sampang stated that "We do not hate the religion, because we know that Christianity is also passed down through the Prophet Isa (Jesus). But its adherents now alter what was taught. There have been many deviations". Defending their arguments with theological support (QS 2: 120), a female student not only described Christians as infidels, but also identified them as those who oppress and mislead Muslims. She strongly agreed if the government obstructs a legal permit to build a church. The establishment of the church, in her view, was a mean to convert Muslims on a large scale. For her, non-Muslims were kafir dhimmi or non-Muslim citizens whose status was subject to Muslim authority (a female student, Sampang, personal communication, May 25, 2019).

\subsubsection{Hostility towards Shia}

Almost all informants labeled Shia as heretical. Kyais and preachers vilified Shia in numerous occasions and soon, this heresy narrative became a collective awareness. During an interview conducted on May 25, 2019, an official of Majelis Ulama Indonesia (MUI) Sampang even considered that it was an achievement to be proud of. Similarly, an official of Nahdlatul Ulama (NU) claimed that almost all the people in Sampang now believe that Shias are heretics. This view stemmed from many local clerics propagating Shia's heresy. On the other hand, this narrative was justified as a pretext exploited by Front Pembela Islam (FPI) to increase its existence and influence in the community. Their justification was to safeguard people's faith from false and misleading teachings. In Probolinggo, an official of MUI also believed that the minority group was not essential so that they did not deserve to conduct community worship openly. "They may carry out their 
community activities, but they are Shias. So, they cannot carry out their activities using banners, sound systems, which highlight their existence. That's not allowed". Interestingly, this discriminatory attitude was from a NU member who claims as moderate accordingly. As an official of MUI, his position was in line with East Java MUI who released a fatwa that Shia is heretical through an official decree in 2012. Ironically, the order was different from their Central MUI who had never banned Shias in Indonesia, but only appealed public to cautiously observe the possibility of extreme sects of Shias such as ghulat and rafidhah [7]. Recently, some corners in the city displayed banners rejecting Shia [8].

\subsubsection{Islam's Incompatibility with Pancasila and Democracy}

One of the narratives that were currently growing in society was that democracy contradicted Islamic teachings. A teacher from Sampang High School stated during an interview on May 24, 2019, that his students who joined FPI believed that democracy and Pancasila were incompatible with Islam. He stated that "In FPI's view, Pancasila and democracy were considered not suitable with Islamic teachings. Because democracy caused Muslims to be legally led by non-Muslims or even the communist PKI". This idea also viewed that state which embraced infidel system of democracy was a "thaghut" (evil) institution, while its apparatus like government officials, civil servants, soldiers, and police, were "anshar thoghut" (defenders of evil). Achsin discussed that this ideology intertwisted with cultural elements justified two female jihadists in Indonesia to commit suicide bombing as a way in combatting defenders of the infidel state [9]. A police officer angrily refuted this idea during an interview on August 2019. He stated that "For example, I am a Muslim. My job as a police officer is considered as anshor thaghut. Well, I pray. I also still read Quran, and do fasting. How can I be vicious? Where?" For extremist ideologies, democracy system is western, bad, and may produce incompetent and infidel leaders.

\subsubsection{Implementation of Sharia Law}

Of the various Islamist agenda, the formalization of Sharia law is the most important. Fealy stated that if we scrutinize their ideology, the implementation of Sharia law is at the heart of the Islamist agenda [10]. They dubbed the idea of formalizing Sharia as "constitutional jihad" pursued as an end or intermediate goal before the establishment of an Islamic state. The application of Islamic Sharia in kaffah (perfect, comprehensive) state stays in the imagination of many Islamic figures in Sampang and Probolinggo. A cleric in Sampang confirmed that he and some ulamas often advised the Mayor to enact Sharia law (Perda). What was always exemplified is Pamekasan's success story - the neighboring city —in implementing the Salam Gate. In this case, he greatly appreciated the courage of FPI. During an interview on May 2019, he stated that "I really appreciate FPI activists who truly maintain people's faith. They have proposed a judicial review of Pak Jokowi's regulation which legalized alcoholic drinks circulation". A local ustad from Probolinggo has confirmed alike during an interview on August 2019. He strongly believed legal implementation of Islamic law was worth supporting action. He stated, "In my opinion, PKS is good, and indeed we like what they pursue. Our kiai supports it too. As far as I know, they are striving for the application of Islamic law in the government. They also strongly reject evil deeds". 


\subsubsection{Legitimate Use of Violence for Amar Ma'ruf Nahi Munkar}

Violent extremism is characterized by an emphasis on using violence as a means to achieve goals. Regardless of their controversy, almost all the informants said that FPI was the one who usually fights for establishing good and prohibiting evil deeds (amar ma'ruf nahi munkar) as a civil vigilante group, for instance, through targeting premises which were perceived as the place of vice. FPI Sampang felt that it had the legitimacy from the community in doing so. Since they often claimed to receive reports from the public about misdeed or immoral activities, they believed that their struggle as Islamic moral police force was part of the da'wah and these actions did not violate the law. Even in the eyes of the people, they had good image (an official of Majelis Ulama Indonesia Sampang, personal communication, May 23, 2019). A female student of an Islamic campus also expressed her acceptance of the use of violence by FPI as it was no longer exclusively owned by the state. She adored FPI's assertive methods because she believed that this was the way perpetration can be reduced and religious activities would be safer from terror. She stated in an interview on August, 2019, that "I like it. Honestly, I like (FPI)...If there weren't them, surely immorality would have been increasingly rampant. Islamic teaching forums are not safe".

\subsection{Networks}

Political Islam objectives can be divided into a spectrum of three; 1) to change or transform political orders, 2) to synchronize the existing political system with the Islamic system, and 3) to promote and advocate Islamic values in the public sphere. In Indonesia, these goals represented a variety of movements. The first group advocating Islamic State or Khilafah was salafi-jihadist groups such as ISIS, Jamaah Ansharud Daulah (JAD), or non-violent Hizbut Tahrir Indonesia (HTI). The second group mainly played a role in the political arena, was Tarbiyah/Ikhwani group. While the third group, like FPI, was a pro-NKRI group but advocated Sharia enforcement. Democratization forced political Islam groups to moderate, but at the same time, it divided them into various factions that promoted different agenda [11]. Islamism or political Islam stance towards democracy can be divided into three; 1) participators (Islam and democracy are compatible), 2) conditionalists (democracy is accepted with certain conditions), and 3) rejecters (Islam is antithetical to democracy) [12]. In Indonesia, pro-khilafah groups such as ISIS or HTI are rejectionists, while the rest- such as Tarbiyah/PKS, NKRI Bersyariah, or FPI-inhibit conditionalist camp. Based on their doctines and religious agendas, Machmudi labelled the latter two camps as new santris [13].

The two santri cities saw flourishing on all variants of Islamist movement. The network was activated by the touch of outside actors who interacted with local figures. Not all of them were prone to violent extremism, such as bombings. Nevertheless, most of them were sympathizers of Islamic state ideas propagated by HTI, opposing towards existing government or legitimizing the use of force and civil vigilante group such as FPI. These organizations were not locals. They were outside actors whose alliance with local communities or leading local figures enabled them to propagate extremist ideas. Their strategies were: 1) Accommodating local traditions or NU religious rituals which they gradually opposed; 2) Infiltrating political parties, Islamic groups, and various existing mass organizations, and building new ummah alliances such as Aliansi Ulama Madura (AUMA); 3 ) Influencing local influential figures (kyai, cleric, teacher, employee); and 4) Exploiting conventional and new media - including social media - to propagate extremist ideas. 
In Sampang's case, the local recruits became agents for spreading radical ideologies in the region while at the same time serving as prominent figures to initiate local organizations that aspired resemblant ideology or objectives. AUMA, for instance, was conformable with HTI in its khilafah ideology. Probolinggo's case also showed the influential role of outsiders. Various groups or institutions - such as Khodimul Ummah Foundation - were affiliated or showed ideological proximity to jihadist/salafi-takfiri/Islamist groups such as JAD or (Jamaah Ansharut Tauhid (JAT) (a local police officer, personal communication, Probolinggo, August, 2019). During an interview conducted on September 13, 2019, an NGO activist claimed that a Salafi's daughter of TK Kartika teacher influenced her mother over decision by dressing girls up in black ISIS-style robes and replica rifles for an Independence Day parade. While most Salafi-Takfiri groups such as JAD were noticeable as part of tsauriyah/revolutionist camp for their blatant support for violent extremism, their numerous counterparts from tadrijiyyah/evolutionist camp might not. Salafis, Ikhwanis, FPI, HTI, or other Islamic pressure groups were fractured in camps when questioning Islam relations with the state, national leadership, Islamic legislation, or preserving Islamic values in public sphere. The two camps of revolutionists and evolutionist differed in their strategy. While the former tended to use direct violence and hard approaches, the latter preferred the softer one. Nevertheless, they might share a common idea in perceiving the current condition of Indonesia as it was resemblant of the phase of Mecca Period. Hence, it required a clandestine movement, implanting new cells, an opposition toward existing government, propagating Islamist thoughts, or setting up a safe house, or "Alqamah house" to control and coordinate their movement. These strategies were adopted to win new recruits' hearts and minds in Probolinggo. For ideology campaign which targeted the youth and middle-class muslims, they used both social media channels and the traditional way such as Friday bulletins. While for expanding and seizing new territory and recruits, the acquisition of mosques and the purchase of strategic houses/land for community centers and educational institutions were crucial, especially in urban areas. A lecturer in an interview on August 2019, sarcastically dubbed the house as "rumah kibul" (camouflage house).

\subsection{Early Detection of Youth Extremism}

In Indonesia, many cases of radicalization among young people revealed unique facts. Unlike other countries, economic and political factors were considered less significant than Islamic recitatiton forums, exposure through educational institutions, and online media. The two santri cities might confirm this statement [14]. Primary, secondary, and higher education institutions were subject to extremist teachings. Penetration usually took advantages of outside-class activities.

In Sampang's case, kyai/cleric/teacher and online media inspired youth's exposure to extremism. This case confirms impeccable role of Madura's kyais as main actors and cultural-political brokers [15]. Today, many local youngsters were involved in extremist movements, or at least in agreement with the radical groups, especially FPI or the likes. Before the ban and dissolve of HTI, it has proliferated and attracted many young people. Since its disbanding, it transformed into a new movement and focused more in initiating new communities. While in Probolinggo, education institutions played a major role in disseminating extremist ideas. The embarrassing gaffe of kindergarten "cultural" parade using black niqab and property rifles could be the best example of how the pedagogic authority of teachers might expose youth to extremist ideas. A teacher and moderate da'wah activist acknowledged that some teachers might advocate Islamist views and were 
indicated to be affiliated with HTI that forced schools to address reprimands (an Islamic cleric, personal communication, August, 2019). Limited access to moderate religious understanding in youth was also an important issue that deserved attention. Religious illiteracy disabled them from having sufficient scientific tools to filter extremist interpretation of religious texts which tended towards choosing shortcuts to study religion online.

\section{CONCLUSIONS}

The public assumption that santri areas being moderate regions is arguably no longer relevant. Extremist thoughts have invaded religious pulpits, education, and the public space. In two santri cities, there has been a hegemonic struggle between moderate Muslims and extremist Muslims. This Discourse separated Muslims into binary dichotomization of normal/extreme, tolerant/intolerant, local/transnational, civilized/uncivilized, old santri/new santri, or old Islam/new Islam. The Islamists have produced three Discourses (with big D); "others", "thaghut", and "legitimate use of violence". Accordingly, they have reproduced five narratives (or discourse with small d), namely: 1) hatred towards Christians, 2) hostility towards Shia, 3) Islam's incompatibility with democracy, 4) formal implementation of Sharia, and 5) legitimate use of violence for commanding good and prohibiting evil (amar ma'ruf nahi munkar).

In Indonesia, democratization forced Islamists to compromise and fracture. Their stances towards democracy are; 1) participators (Islam is compatible with democracy), 2) conditionalists (democracy accepted with certain conditions), and 3) rejecters (Islam is antithetical to democracy). The rejectionist groups such as ISIS or HTI and many conditionalist groups — such as Tarbiyah/PKS, FPI - and their affiliation movements have been present in Sampang and Probolinggo. Their strategies may vary: 1) clandestine movements by infiltrating existing Islamic organizations or communities to build new ummah alliances such as AUMA, 2) propagating ideology by exploiting social media channels and traditional print media promoting opposition to the government, and 3) building safe house or movement control house, "kibul house", or "Alqamah house". The Islamists were also targeting educational institutions, youth, and middle-class muslims to spread radical religious understanding. By utilizing pedagogical figures and social media, they succeeded in instilling awareness to (female) students who believe that the use of violence is justifiable for ordering good and prohibiting evil (amar ma'ruf and nahi munkar).

\section{REFERENCES}

[1] D. B. Subedi, "Early Warning and Response for Preventing Radicalization and Violent Extremism," Peace Rev., vol. 29, no. 2, pp. 135-143, 2017.

[2] S. Willy \& T. Octastefani, "Menjinakkan Industrialisasi dengan Politik Santri," in Rezim Lokal di Indonesia: Memaknai Ulang Demokrasi Kita, Pertama., L. Bayo, Ed. Jakarta: Yayasan Pustaka Obor Indonesia, PolGov UGM, University of Oslo), 2018, p. 244.

[3] A. Z. Hamdi, "Klaim Religious Authority dalam Konflik Sunni-Syi'i Sampang Madura," Islam. J. Stud. Keislam., 2014.

[4] "Pawai murid TK bercadar dan bawa replika senjata, 'isyarat ancaman radikalisme mulai mengakar' - BBC News Indonesia." [Online]. Available: https://www.bbc.com/indonesia/indonesia-45248639. [Accessed: 12-Dec-2019]. 
[5] D. M. A. Lexy J. Moleong, "Metodologi Penelitian Kualitatif (Edisi Revisi)," PT. Remaja Rosda Karya, p. 157, 2019.

[6] F. Wijsen, “"There are radical Muslims and normal Muslims': An analysis of the discourse on Islamic extremism," Religion, vol. 43, no. 1, pp. 70-88, Jan. 2013.

[7] "Ajaran Syiah, menurut MUI, tidak dilarang di Indonesia - BBC News Indonesia." [Online].

Available:

https://www.bbc.com/indonesia/berita_indonesia/2015/10/151025_indonesia_syiah_bogor.

[Accessed: 12-Dec-2019].

[8] "Banner Tolak Syiah Terpasang di Probolinggo, Pihak Terkait Dipertemukan." [Online]. Available: https://news.detik.com/berita-jawa-timur/d-4759617/banner-tolak-syiah-terpasang-diprobolinggo-pihak-terkait-dipertemukan. [Accessed: 12-Dec-2019].

[9] M. Z. Achsin, "Culture and Role of Woman in Terrorism in Indonesia. Case Studies: Suicide Bombings in Surabaya and Sibolga," Int. J. Eng. Adv. Technol., vol. 8, no. 5C, pp. 873876, Sep. 2019.

[10] G. Fealy, "ISLAMIC RADICALISM IN INDONESIA : The Faltering Revival? Author ( s ): Greg Fealy Source : Southeast Asian Affairs , ( 2004 ), pp . 104-121 Published by : ISEAS Yosuf Ishak Institute Stable URL : http://www.jstor.org/stable/27913255 The Faltering Reviv," no. 2004, pp. 104-121, 2016.

[11] M. Ayoob, The Many Faces of Political Islam. 2016.

[12] K. Bokhari and F. Senzai, Political Islam in the Age of Democratization. New York: Palgrave Macmillan US, 2013.

[13] Y. Machmudi, "The emergence of new santri in Indonesia," J. Indones. Islam, 2008.

[14] "Youth vulnerability to violent extremist groups in the Indo-Pacific - GSDRC." [Online]. Available: https://gsdrc.org/publications/youth-vulnerability-to-violent-extremist-groups-in-theindo-pacific/. [Accessed: 12-Dec-2019].

[15] Y. Pribadi, "Religious networks in Madura pesantren, Nahdlatul Ulama and Kiai as the core of santri culture," Al-Jami'ah, vol. 51, no. 1, pp. 1-32, 2014. 